Haya: The Saudi Journal of Life Sciences

Abbreviated Key Title: Haya Saudi J Life Sci ISSN 2415-623X (Print) |ISSN 2415-6221 (Online) Scholars Middle East Publishers, Dubai, United Arab Emirates Journal homepage: https://saudijournals.com/sjls

Original Research Article

\title{
Selection of Culture Media and Laboratory Evaluation of Fungitoxicants for the Pathogen Causing Early Blight Disease of Potato
}

Uttam Bouri* , Soumen Pal and Bholanath Mondal

Department of Plant Pathology, Palli-Siksha Bhavana (Institute of Agriculture), Visva-Bharati, Sriniketan, West Bengal 731236, India

DOI: $10.36348 /$ sjls.2020.v05i10.004

| Received: 06.10.2020 | Accepted: 20.10.2020 | Published: 29.10.2020

*Corresponding author: Uttam Bouri

\section{Abstract}

Early blight is the most common and devastating disease of potato (Solanum tuberosum L.) caused by Alternaria solani (Ellis \& Martin) Jones and Grout. In vitro experiments were conducted during 2017-2018 to search appropriate growth medium of $A$. solani, as well as suitable fungi toxicant through quick screening methods. Seven different growth medium were used to culture the fungus in laboratory. Mycelial growth was very fast in Potato Dextrose Agar (PDA) followed by Richards's Agar (RA) medium. Intermediate growth habit was recorded in Sabouraud's Agar (SA), Czapek's Dox Agar (CDA) and Potato Carrot Extract Agar (PCEA). The growth was very slow in Oat Meal Agar (OMA) and Malt Extract Agar (MES) at 72 hours of incubation. On bioefficacy evaluation, Infield Ayur showed very negligible effect to restrict mycelial growth and conidia formation, whereas Indofil M-45 (mancozeb) was more efficacious followed by Indofil Z-78 (zineb), Merger (tricyclazole + mancozeb) and Ishaan (chlorothalonil). Selection of most suitable culture media is essential for efficient growth of the fungus and its detail study. Quick and simple method to select effective fungicides within 48-72 hours is very much helpful for developing suitable disease management strategy.

Keywords: Alternaria solani, early blight, potato, culture media, fungicides, management.

Copyright (C) 2020 The Author(s): This is an open-access article distributed under the terms of the Creative Commons Attribution 4.0 International License (CC BY-NC 4.0) which permits unrestricted use, distribution, and reproduction in any medium for non-commercial use provided the original author and source are credited.

\section{INTRODUCTION}

Potato (Solanum tuberosum L., Family: Solanaceae) is one of the most important remunerable solanaceous vegetable crop either for local consumption and exportation in the world. In volume of production it ranks fourth in the world after wheat, rice and maize [1, 9]. The potato crop is prone to affected by numbers of diseases caused by fungi, bacteria, virus, viroid, mycoplasma like organism or nematodes but fortunately relatively few reach serious proportions in any of the growing areas $[3,7]$. Among them early blight caused by Alternaria solani (Ellis \& Martin) Jones and Grout is one of the most destructive fungal foliar diseases in many potato growing regions. In susceptible cultivars, it leads to early defoliation and death of the crops. Early blight is widespread in most areas where potatoes or tomatoes are grown, but is especially prevalent in the tropics and temperate zones. The symptoms appeared mainly on leaves and stems, and in severe condition on tubers. Initially the symptoms were observed on lower most leaves i.e. older leaves, which consist of small, oval to irregular, dark brown to black, single to numerous necrotic spots. These spots become enlarged to form concentric rings that appeared as 'target-board' like appearance. Damage of early blight is due to premature defoliation of the plant. Photosynthesis rates increase and respiration rates decrease in apparently healthy tissues. Physiological changes are difficult to measure and evaluation of crop loss is based on the level of disease and thus causing losses of 50 to 86 per cent in tuber yield [5]. The disease on potato was as good in warm and moist conditions are more favourable for A. solani. The present study was undertaken to observe the mycelium growth (Colony diameter) of different culture media and rapid laboratory evaluation of fungicides (mycelial growth and conidia formation) against early blight disease of potato.

\section{MATERIALS AND METHODS Collection and isolation of disease leaf samples} Potato leaves showing typical disease symptoms (Plate 1) were collected from farmers' fields of Binuria, Birbhum, West Bengal in morning hours. These fields were located at an average altitude of 58.9 meter above MSL and $23^{\circ} 39^{\prime} \mathrm{N}$ latitude and $87^{\circ} 42^{\prime} \mathrm{E}$ longitude. The experiments were carried out during 2017-18 in Plant Pathology laboratory, Palli-Siksha Bhavana (Institute of Agriculture), Visva- Bharati. The 
pathogen was isolated in PDA medium from the collected diseased sample, and pure culture was prepared for further progress of the work.

\section{Suitable culture media preparation}

The purified culture of the fungus was inoculated into seven different culture media viz. Potato dextrose agar (PDA), Malt extract agar (MEA), Czapek's dox agar (CDA), Oat meal agar (OMA), Sabouraud's agar (SA), Potato carrot extract agar
(PCEA) and Richards agar (RA). To prepare 1 litre, required amount of different ingredients of such media are mentioned in Table 1. The general preparation of different culture medium was same in all the cases and then autoclaved at $15 \mathrm{psi}$ pressure for 20 minutes. Three replications were maintained in each medium and the radial growth of the mycelium were measured at $24 \mathrm{~h}$ interval and daily radial growth rates were calculated in CRD.

Table-1: Ingredients of different culture media for A. solani

\begin{tabular}{|l|l|}
\hline Name of media & Ingredients* \\
\hline PDA & Peeled potato-200g, dextrose-20g, agar-agar-20g \\
\hline MEA & Malt extract-20g, agar-agar-20g \\
\hline CDA & $\begin{array}{l}\mathrm{C}_{12} \mathrm{H}_{22} \mathrm{O}_{11}-30 \mathrm{~g}, \mathrm{NaNO}_{3}-2 \mathrm{~g}, \mathrm{KH}_{2} \mathrm{PO}_{4}-1 \mathrm{~g}, \mathrm{MgSO}_{4} \cdot 7 \mathrm{H}_{2} \mathrm{O}-0.50 \mathrm{~g}, \mathrm{FeCl}_{3} \cdot 6 \mathrm{H}_{2} \mathrm{O}-0.01 \mathrm{~g}, \mathrm{KCI}- \\
0.50 \mathrm{~g}, \text { agar-agar-20g }\end{array}$ \\
\hline OMA & Oat meal powder-40g, agar-agar-20g \\
\hline SA & Dextrose-40g, peptone-10g, agar-agar-20g \\
\hline PCA & Peeled potato-200g, carrot-200g, agar-agar-15g \\
\hline RA & $\begin{array}{l}\mathrm{C}_{12} \mathrm{H}_{22} \mathrm{O}_{11}-50 \mathrm{~g}, \mathrm{KNO}_{3}-10 \mathrm{~g}, \mathrm{KH}_{2} \mathrm{PO}_{4}-5 \mathrm{~g}, \mathrm{MgSO}_{4} \cdot 7 \mathrm{H}_{2} \mathrm{O}-2.50 \mathrm{~g}, \mathrm{FeCl}_{3} \cdot 6 \mathrm{H}_{2} \mathrm{O}-0.02 \mathrm{~g}, \text { agar- } \\
\text { agar-15g }\end{array}$ \\
\hline *Distilled water required for each medium to make up the volume of 1 litre \\
\hline
\end{tabular}

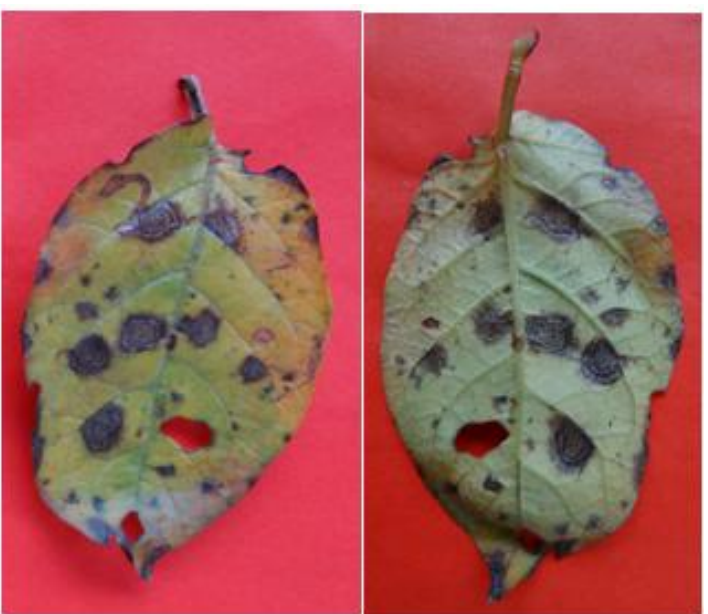

Plate-1: Characteristic symptoms of early blight of potato

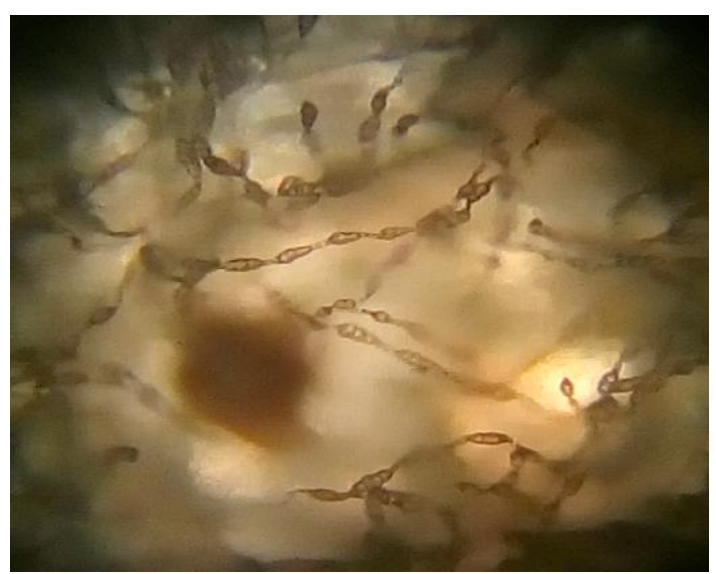

Plate-2: Mycelial growth along with conidial germination in aqueous medium

\section{Bio-efficacy evaluation of fungicides}

Seven fungitoxicants were selected for the study (Table 2). Aqueous suspension of commercial preparation was used for evaluation. Diseased leaves containing white mycelial growth under side were collected from infested field in morning hours. Leaf bits were prepared measuring nearly $1.0 \mathrm{~cm} \times 0.5 \mathrm{~cm}$ containing both diseased and healthy tissue. Three such bits were placed in a petriplate containing fungicide suspension or sterile filtered tap water. Initially these fungicidal suspensions were agitated for better contact with the leaf bits and the process was repeated after three hours. There were three replications for each treatment. The plates were incubated at room temperature for $48 \mathrm{hrs}$ and then observed under microscope (Compound light microscope, 10X objective) to record the extent of mycelial growth and conidia formation in treatment suspensions (Plate 2). A rating scale was also prepared as developed by Mondal et al. [6].

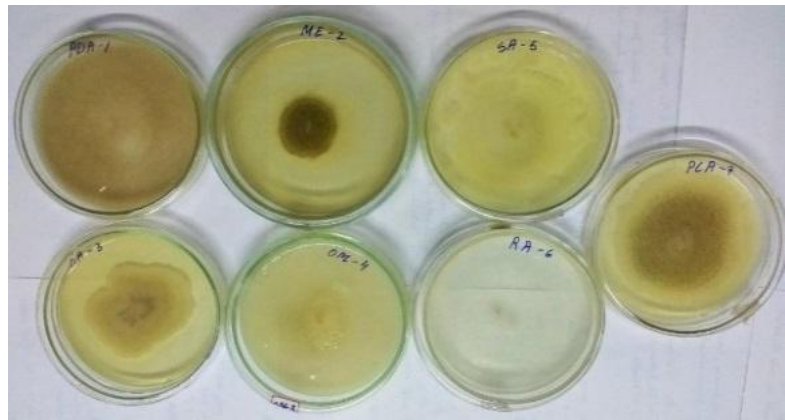

Plate-3: Screening of suitable culture media for growth of $\boldsymbol{A}$. solani 


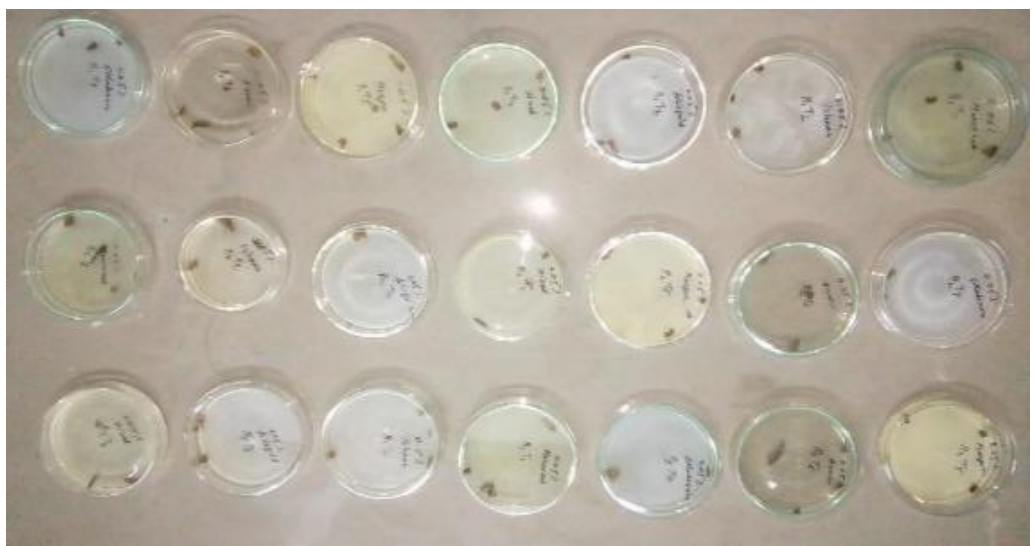

Plate-4: Bioefficacy study of different fungitoxicants against $A$. solani

Table-2: Fungitoxicants used for rapid laboratory evaluation

\begin{tabular}{|l|l|l|}
\hline Sl. No. & Fungicides & Active ingredient and formulation \\
\hline 1. & Indofil M-45 (Indofil Industries Ltd.) & Mancozeb 75\% WP \\
\hline 2. & Foliogold (Syngenta India Ltd.) & Chlorothalonil 33\% + Metalaxyl 3.3\% SC \\
\hline 3. & $\begin{array}{l}\text { Ethaboxam (Sumitomo Chemical } \\
\text { India Ltd.) }\end{array}$ & Ethaboxam 40\% SC \\
\hline 4. & Ishaan (Rallis Tata Enterprise) & Chlorothalonil 75\% WP \\
\hline 5. & Indofil Z-78 (Indofil Industries Ltd.) & Zineb 75\% WP \\
\hline 6. & Merger (Indofil Industries Ltd.) & Tricyclazole 18\% + Mencozeb 62\% \\
\hline 7. & Infield Ayur (Infield Organics Ltd.) & $\begin{array}{l}\text { Eugenol 00.10\% + Potassium salt of fatty acids } 02.00 \%+ \\
\text { Sodium salts 97.90\% W/W }\end{array}$ \\
\hline
\end{tabular}

\section{RESULTS AND DISCUSSION \\ Effect of different culture media}

Different artificial solid media were used to find out the best medium for growth of the isolate of $A$. solani. Colony diameter was measure and recorded for comparison. The results are presented in Table 3. The fungus showed slight difference in its growth on different solid media. The maximum radial growth of $A$. solani was measured on Potato Dextrose Agar with colony diameter of 26.03, 63.20 and $87.90 \mathrm{~mm}$ at 24,48 and 72 hours followed by Richard's agar 22.17, 55.37 and $81.17 \mathrm{~mm}$ at 24, 48 and 72 hours and least colony diameter of $09.67,25.33$ and $36.60 \mathrm{~mm}$ at 24,48 and 72 hours was observed in Oat meal agar. A good growth of the fungus was also observed in other media, i.e. colony diameter in Potato carrot extract agar was 11.20, 32.23 and $52.43 \mathrm{~mm}$, Malt extract agar was 18.13, 39.23 and $46.13 \mathrm{~mm}$, Czapek's agar was 14.07, 40.93 and 56.10 $\mathrm{mm}$ and Sabouraud's agar was 16.10, 43.67 and 64.90 $\mathrm{mm}$ at 24, 48 and 72 hours (Plate 3 and Figure 1).

Table-3: Growth of A. solani on different artificial solid media

\begin{tabular}{|c|c|c|c|c|}
\hline \multirow[b]{2}{*}{ Media } & \multicolumn{3}{|c|}{ Colony diameter $(\mathbf{m m})$} & \multirow[b]{2}{*}{ Mean } \\
\hline & 24 hrs. & 48 hrs. & 72 hrs. & \\
\hline Potato dextrose agar & $\begin{array}{l}26.03 \\
(5.13 *\end{array}$ & $\begin{array}{l}63.20 \\
(7.96)\end{array}$ & $\begin{array}{l}87.90 \\
(9.40)\end{array}$ & 59.04 \\
\hline Malt extract agar & $\begin{array}{l}18.13 \\
(4.30)\end{array}$ & $\begin{array}{l}39.23 \\
(6.28)\end{array}$ & $\begin{array}{l}46.13 \\
(6.79)\end{array}$ & 34.50 \\
\hline Czapek's agar & $\begin{array}{l}14.07 \\
(3.81)\end{array}$ & $\begin{array}{l}40.93 \\
(6.43)\end{array}$ & $\begin{array}{l}56.10 \\
(7.48)\end{array}$ & 37.03 \\
\hline Oat meal agar & $\begin{array}{l}9.67 \\
(3.18) \\
\end{array}$ & $\begin{array}{l}25.33 \\
(5.07)\end{array}$ & $\begin{array}{l}36.60 \\
(6.08)\end{array}$ & 23.87 \\
\hline Sabouraud's agar & $\begin{array}{l}16.10 \\
(4.06)\end{array}$ & $\begin{array}{l}43.67 \\
(6.64)\end{array}$ & $\begin{array}{l}64.90 \\
(8.08)\end{array}$ & 41.56 \\
\hline Richards agar & $\begin{array}{l}22.17 \\
(4.76)\end{array}$ & $\begin{array}{l}55.37 \\
(7.46)\end{array}$ & $\begin{array}{l}81.17 \\
(9.01)\end{array}$ & 52.90 \\
\hline Potato carrot extract agar & $\begin{array}{l}11.20 \\
(3.41)\end{array}$ & $\begin{array}{l}32.23 \\
(5.72)\end{array}$ & $\begin{array}{l}52.43 \\
(7.20)\end{array}$ & 31.96 \\
\hline $\operatorname{SEm}( \pm)$ & 0.21 & 0.30 & 0.44 & \\
\hline C.D. $(p=0.01 \%)$ & 0.62 & 0.90 & 1.30 & \\
\hline
\end{tabular}

*This figure in parenthesis is square-root transformed values. 
It was revealed from the Table 3 that the mycelial growth was very fast in Potato dextrose agar followed by Richard's agar medium, whereas it was intermediate in Sabouraud's agar, Czapek's agar and
Potato carrot extract agar medium. The growth was recorded very slow in Oat meal agar and Malt extract agar medium.

Table-4: Efficacy of different chemicals used for rapid laboratory evaluation against $A$. solani causing early blight of potato

\begin{tabular}{|c|c|c|c|c|c|c|}
\hline \multicolumn{4}{|c|}{ Extent of mycelial growth } & \multicolumn{3}{|c|}{ Extent of conidia formation } \\
\hline \multirow[t]{2}{*}{ Treatment } & \multicolumn{6}{|c|}{ \% concentration of fungicide formulation } \\
\hline & 0.1 & 0.05 & 0.025 & $\mathbf{0 . 1}$ & $\mathbf{0 . 0 5}$ & 0.025 \\
\hline $\mathrm{T}_{1}$ & Very scanty & Scanty & Medium & Few & Medium & Medium \\
\hline $\mathrm{T}_{2}$ & Scanty & Medium & Profuse & Few & Medium & Medium \\
\hline $\mathrm{T}_{3}$ & Medium & Medium & Profuse & Medium & Medium & Medium \\
\hline $\mathrm{T}_{4}$ & Scanty & Scanty & Medium & Few & Medium & Medium \\
\hline $\mathrm{T}_{5}$ & Scanty & Medium & Medium & Few & Medium & Medium \\
\hline $\mathrm{T}_{6}$ & Medium & Medium & Profuse & Medium & Medium & Huge \\
\hline $\mathrm{T}_{7}$ & Medium & Medium & Profuse & Medium & Huge & Huge \\
\hline $\mathrm{T}_{8}$ & Profuse & Profuse & Profuse & Huge & Huge & Huge \\
\hline \multicolumn{7}{|c|}{$\mathrm{T}_{1}=$ Indofil M-45, $\mathrm{T}_{2}=$ Ishaan, $\mathrm{T}_{3}=$ Foliogold, $\mathrm{T}_{4}=$ Indofil $\mathrm{Z}-78, \mathrm{~T}_{5}=$ Merger, $\mathrm{T}_{6}=$ Infield Ayur, $\mathrm{T}_{7}=$ Ethaboxam and $\mathrm{T}_{8}=$ Control. } \\
\hline $\begin{array}{l}\text { Where, } \\
\text { Nil = absent } \\
\text { Very scanty/ } \\
\text { Scanty/few = } \\
\text { Medium = > } \\
\text { Profuse/hug } \\
\text { Source of ra }\end{array}$ & $\begin{array}{l}\text { hed/unbranch } \\
=10 \text { or }<10 \\
25 \text { branched/u } \\
\text { branched/unb } \\
\text { ranched/unbr } \\
\text { : Mondal et a }\end{array}$ & $\begin{array}{l}\text { e or conid } \\
\text { nched/unb } \\
\text { d hyphae } \\
\text { hyphae or } \\
\text { yphae or c }\end{array}$ & $\begin{array}{l}\text { nd the leaf } \\
\text { hyphae o } \\
\text { dia around } \\
\text { around th } \\
\text { around the }\end{array}$ & $\begin{array}{l}\text { ia around } \\
\text { f tissue. } \\
\text { ssue. } \\
\text { sue. }\end{array}$ & tissue. & \\
\hline
\end{tabular}

\section{Effect of fungitoxicants on mycelial growth and conidia formation}

Good variation was recorded (Table 4) in respect to effect of different fungitoxicants on mycelial growth and conidia formation (Plate 4). Among the treatments, botanical based treatment i.e. Infield Ayur (Eugenol $00.10 \% \mathrm{~W} / \mathrm{W}+$ Potassium salt of Fatty Acids $02.00 \% \mathrm{~W} / \mathrm{W}+$ Sodium salts $97.90 \% \mathrm{~W} / \mathrm{W}$ ) showed very negligible effect on Alternaria solani. Indofil M45 (Mancozeb) and Indofil Z-78 (Zineb) was very much effective to inhibit the mycelial growth and conidia formation. They were more or less similar to restrict the fungal growth. Mancozeb when associated with Tricyclazole (Merger) recorded better than Foliogold (Chlorothalonil + Metalaxyl). Adequate growth inhibition (both mycelia and conidia) was also recorded in Ishaan (chlorothalonil) while Ethaboxam was inadequate. Earlier, similar method was utilized successfully in selecting fungicides for management of fruit and vine rot of pointed gourd caused by Phytophthora melonis [8]. In this case infected fruit tissue was used. Khatua et al. [4] tested performance of the fungicides against Phytopthora infestans in aqueous environment using mycelial disc from agar medium as inoculum. Mondal et al. [6] reported some effective fungicides through rapid laboratory evaluation method against Phytophthora infestans in aqueous environment causing late blight of potato. Bouri et al. [2] recorded more or less similar results both in field and laboratory conditions against Alternaria solani causing early blight of potato.

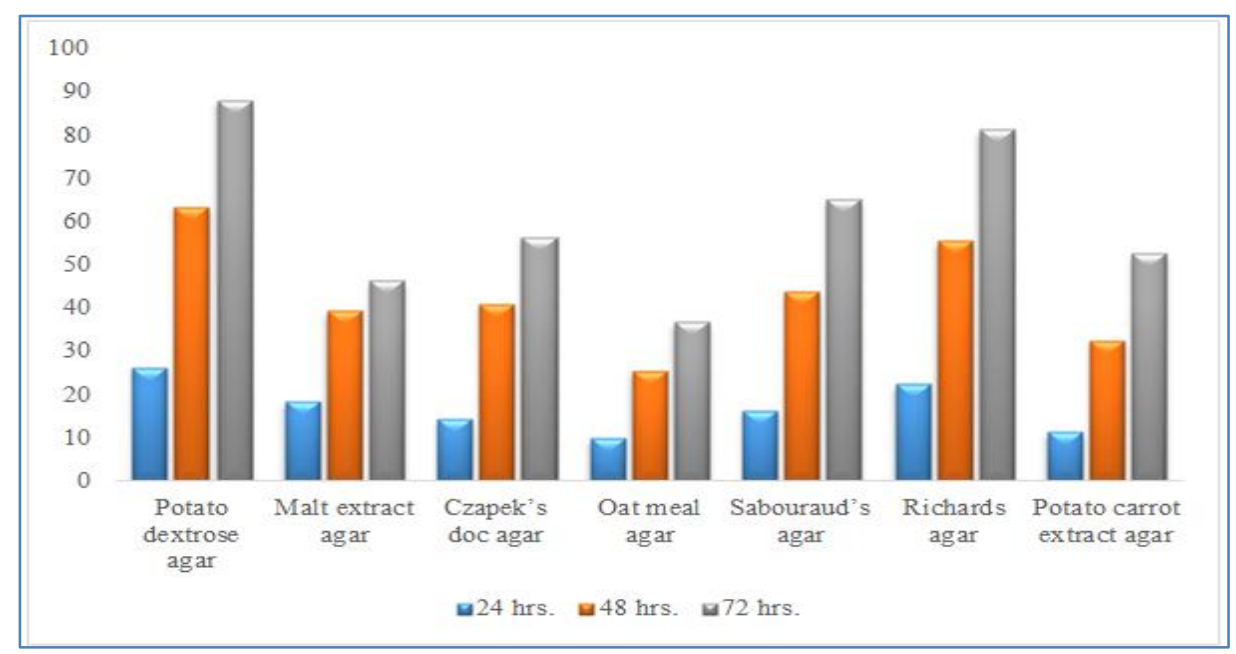

Fig-1: Screening of suitable culture media 


\section{CONCLUSION}

Potato dextrose agar or Richards's agar medium can be used successfully for artificial culturing of the pathogen. The methods used in this study are very much effective because fungitoxicants can quickly and easily be evaluated against the pathogen causing early blight of potato within 48-72 hours. Aqueous suspension of Mancozeb and Zineb revealed more effective to suppress the pathogenic growth in laboratory that can be applied in field to manage the pathogen causing early blight of potato.

\section{Conflict of interest} of interest.

The authors declare that they have no conflict

\section{ACKNOWLEDGEMENT}

The authors are thankful to Sri Shyam Mete, one of the progressive farmers at Benuria who was consented us to carry out for the field study. The study is a part of M. Sc. dissertation of the first author, Sri Uttam Bouri under the guidance of the third author, Dr. Bholanath Mondal. Rest one was assisted in different ways during the course of the study.

\section{REFERENCE}

1. Bowen, W. T. (2003). Water productivity and potato cultivation. In: Water Productivity in Agriculture Limits and Opportunities for Improvement (Eds. J.W. Kijne, R. Barker and D. Molden). CAB International, pp. 229-238.

2. Bouri, U., Pal, S., Mondal, B., \& Singh, R. K. (2020). Management of early blight of potato through fungicides under field and laboratory conditions. European Journal of Biotechnology and Bioscience, 8(2): 31-34.

3. Gupta, A. B. (2006). Epidemiology and management of early blight of potato. $\mathrm{Ph} . \mathrm{D}$. thesis, Narendra Dev University of Agriculture and Technology, Faizabad (U.P.) India.

4. Khatua, D.C., Mondal, B. and Jana, M. (2013). Host range, medium for isolation and technique for bioassay against Phytopthora nicitianae: the causal pathogen of leaf rot of betelvine. Res. On crops, 14(2): 592-595.

5. Mathur, K., \& Shekhawat, K.S. (1986). Chemical control of early blight in Kharif sown tomato. Indian J. Mycol. Pl. Pathol., 16: 235- 238.

6. Mondal, B., Pauria, N. K., \& Khatua, D. C. (2015). Rapid laboratory evaluation of fungicides against Phytophthora infestans causing late blight of potato. Journal of Scientific Research \& Reports. 4(2):168-173.

7. Mondal, B. and Mondal, P. (2014). Management of late blight, severe mosaic and PLRV of potato. International Journal of Plant, Animal and Environmental Sciences. 4(4):144- 149.

8. Saha, G., Das, S. N., \& Khatua, D. C. (2004). Fruit and vine rot of pointed gourd etiology, epidemiology and management. J. Myco. pathol. Res., 42: 73-81.

9. Shekhawat, G. S. (2001). Potato production, land utilization issues related to technology, storage, processing and export. Journal of Indian Potato Association, 28(1): 8-9. 